\title{
Influence of Select Macro-economic Factors on Investments in Indian Mutual Funds Market
}

\author{
Ms. Nirmala Daita ${ }^{1} \quad$ Dr. Varsha Thakre ${ }^{2}$ \\ 1.Ph.D Research scholar, Department of Business Management, RTM Nagpur University, Nagpur \\ 2.Research supervisor, Head, Department of Commerce, Annasaheb Gundewar College, Nagpur
}

\begin{abstract}
The Indian financial market is growing fast by channelizing house hold savings through various investment avenues, among which mutual funds become more popular in recent times. The growth of the mutual fund market depends on the investment environment of the country. There are several macroeconomic factors influences the investment environment, which in turn helpful for assessing the market risk and investment desirability. The present paper aim to study the influence of select macro-economic factors on investment in Indian mutual funds market. The data pertaining to the select macroeconomic variables gathered from secondary sources for a period of 28 years (1990-91 to 2017-18). The causal relationship between select macro-economic variables and their influence on the Mutual funds market has been analyzed by using descriptive statistics with suitable test statistics, correlation matrix, Augmented Dickey-Fuller (ADF) test, and Granger causality test. The study results conclude that the select macroeconomic variables do not have any significant influence on investments in Indian Mutual funds market for valid market predictions and worthwhile investment decisions.

Keywords: Macroeconomic variables, S \& P CNX Nifty, correlation matrix, Augmented Dickey-Fuller (ADF), Granger causality.
\end{abstract}

DOI: $10.7176 /$ RJFA/12-11-01

Publication date:June $30^{\text {th }} 2021$

\section{Introduction:}

The Indian financial market today is one of the fastest growing markets of the world. Mutual funds in India have emerged as a critical institutional link among various financial segments like savings, capital markets and the corporate sector. In addition, mutual funds have given a new direction to the flow of personal savings and enabled small and medium investors in remote rural and semi-urban areas to reap the benefits of stock market investments. With the growing complexity of the securities market, busy individual investors seek the avenue of mutual funds to achieve above-average returns on their investments. Mutual funds are, therefore, the investment vehicle for all sections of investors - small, medium and large, 'risk-averse' and 'risk taking' individuals as well as institutions and become more popular in recent times. The development of Indian mutual fund market depends on the investment environment of the country. There are some key macroeconomic factors which influences the mutual fund market in the country.

\section{Statement of the Problem}

The economic progress of a country to a greater extent depends on the growth of its financial sector. Financial market plays a vital role in the financial sector by channelizing the investments to create a healthy investment environment. While making investments in mutual funds, it is worthwhile to understand the investment environment of the country. The key macroeconomic indicators of an economy can demonstrates the prevailing status of investment environment in a country. In fact, the influence of macroeconomic factors have a direct bearing on the investment environment, which in turn affects the investments in mutual funds as well as stock market of the country. Hence, a thorough analysis on the influence of macroeconomic factors on investment in mutual fund market can be helpful to predict the market movements and to judge the investment desirability. In this context, great deal of interest generated among academician, researchers, investors, investment advisers, regulating authorities and government bodies to identify influence of macroeconomic factors on the investment market. Based on the aforesaid milieu, the investigator attempted to identify the influence of key macroeconomic variables on mutual funds market in order to derive valid predictions.

\section{Review of literature}

The review of earlier studies noticed that there are several research work undertaken to study the relationship between investment market and key macro- economic factors like inflation, exchange rate, and interest rate, political events etc. Nonetheless, the present study reviewed various literatures pertaining to investments in mutual funds from different angles. Some of the relevant studies are presented below.

The research studies conducted by Bogle (1992), Ippolito (1992), Ramasamy and Young (2003), Sikdar and Singh (1996), Wilcox (2003) and Singh and Chander (2004) were considered past performance of mutual funds as a criteria for investors to make investment in mutual funds. 
G. Dinesh Kumar and Mihir Dash (2008) made an attempt to study the macroeconomic variables effect on return (NAV) of sleeted mutual fund schemes. The study results found that among $35.29 \%$ of sample scheme the return and variance of return were not affected by macroeconomic variables. The study applied Granger Casualty model to identify macroeconomic variables which affect the NAV significantly.

The research study conducted by Mohammadreza Monjazeb and Esmaeel Ramazanpour (2013) found that exchange rate and inflation have a positive effect of on the mutual fund return. However, the study results concluded that in the long run macroeconomic factor will not affect the returns of mutual funds.

Emily chelangat kariuki (2014) found that $70.9 \%$ mutual fund's performance in Kenya influenced by five macroeconomic variables such as money supply, interest rate, inflation rate, GDP and exchange rates. Among these factors Money supply, inflation rates, interest rates, GDP were found positive influence, while the exchange rate found significant negative influence on the return of Kenyan's mutual funds.

Badrinath and Gubellini (2012) in their research study examined the performance of mutual fund under business cycle in order to identify funds which exhibit cyclical performance. The study results revealed that both mid-cap and small-cap growth equity fund can able to exhibit performance, while value funds were not able to do so.

Some researchers have studied the investor's behavior for making investment in mutual funds. Allen and Parwards (2006) investigated mutual fund investor's behavior response on merger of Australian mutual fund companies by using regression analysis. The study found that rather than mergers contribute for increase in mutual fund investment, the investors withdrew target funds immediately before and after the merger occurs. Watson and Funck (2012) examined the trading behavior of short-term seller and found that an increase in short selling with the level of cloudiness and a decrease in short selling noticed three days prior to a cloudy day.

Tony Chieh - Tse Hou (2012) examined the return persistence and investment timing decisions in Taiwanese domestic equity mutual funds. The study results noticed that funds performed well (poorly) in the preceding year tend to continue performing well (poorly) in the subsequent year, however investor's timing performance is negatively related to fund performance. Deepak Chawla (2014) in his research study attempted to understand the mutual fund buying behavior of the retail investors to identify the various attributes that needs consider important while investing in mutual fund. The study found that Credibility of the fund and Miscellaneous features of the fund are important.

Broadly, the review of the existing literature on mutual funds and the macro-economic factors, revealed that few literatures is available by focusing some of the macro-economic factors such as consumer price index, foreign exchange rates, national income, inflation, interest rates, GDP etc. The present study deviates to certain extent by considering some other key macro-economic variables in order to analyze their influence on investments in Indian mutual market.

\section{Objectives of the Study}

Based on the research gap identified, the present study focused on the following objectives:

1. To identify the long run relationship of select macro-economic factors on investments in Indian mutual funds market

2. To examine the influence of select macro-economic factors on investments in Indian mutual funds market

\section{Hypotheses of the Study}

In order to achieve the above objectives, the investigator attempted to test empirically the causal relationship between macro-economic variables and investments in Indian mutual funds market by considering S\&P CNX Nifty as bench mark index (dependent variable) and key macro -economic variables as dependent variables. The key economic variables included in the study are; RBI Bank Rate, Domestic Savings, Forex Reserves, Gross Domestic Capital Formation (GDCF), Gross Domestic Product (GDP), Broad Money (M3), Per-capita Gross National Product (GNP) and Wholesale Price Index (WPI) (as independent variables). The following Null hypotheses are developed for want of statistical analysis and inference.

$\mathbf{H}_{01}$ : RBI Bank Rate does not influence the investments in Indian mutual funds market

H02: Domestic Savings does not influence the investments in Indian mutual funds market

H03: Forex Reserves does not influence the investments in Indian mutual funds market

H04: GDCF does not influence the investments in Indian mutual funds market

Ho5: GDP does not influence the investments in Indian mutual funds market

Ho6: Money Supply does not influence the investments in Indian mutual funds market

$\mathbf{H}_{07}$ : Per-capita GNP does not influence the investments in Indian mutual funds market

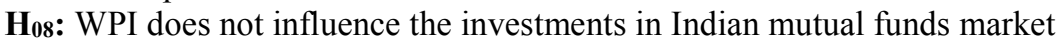




\section{Data Collection}

The relevant data needed for the study have been gathered from secondary sources. The data relating to the key macroeconomic variables for a period of 28 years (1990-91 to 2017- 18) gathered from the Economic Survey and Handbook of Statistics on Indian Economy. The data pertaining to the mutual fund industry was gathered from the web sites of www.sebi.gov.in, www.amfiindia.com.

\section{Data Analysis and Tools Employed}

For the purpose of conducting in-depth analysis the data relating to macro-economic variables have been processed through MS-Excel to conduct the descriptive statistics and correlation matrix. Under descriptive statistics examined mean, median, maximum and minimum values; standard deviation, skewness, kurtosis, Jarque-Bera (JB) and probability were examined. The correlation matrix helped to know the relationship between the variables on which we need to apply Granger causality test. Subsequently, unit root Augmented Dickey-Fuller (ADF) test has been conducted on all the variables to test their stationarity, in order to fulfill the pre-condition of Granger causality. Finally, Granger causality test was applied to measure the causal relationship between macro-economic variables and their influence on investment of mutual funds in the market.

\section{Results and Discussion}

The analysis of descriptive statistics to examine the influence of macro-economic variable on investment of mutual funds revealed that the standard deviation value of forex reserves is relatively high volatility around its mean value among other selected variables. The Skewness values of all the variables is found positive. However, the Kurtosis values found that forex reserves, Broad Money, GDCF at Current Prices and S \& P CNX Nifty were found positively skewed and the rest were negatively skewed. The calculated value of Jarque-Bera (JB) statistic is very high, while probability is zero and the test statistics follows a chi-square distribution with 2 degrees of freedom. The summarized results indicates that the null hypotheses are accepted.

\begin{tabular}{|l|l|l|l|l|l|l|l|l|l|} 
Table 1: Descriptive Statistics - Key Macroeconomic Variables \\
\hline & $\begin{array}{l}\text { Bank } \\
\text { Rate }\end{array}$ & $\begin{array}{l}\text { Domestic } \\
\text { Savings }\end{array}$ & $\begin{array}{l}\text { Forex } \\
\text { Reserves }\end{array}$ & $\begin{array}{l}\text { GDCF at } \\
\text { Current } \\
\text { Prices }\end{array}$ & $\begin{array}{l}\text { GDP at } \\
\text { Factor } \\
\text { Cost }\end{array}$ & $\begin{array}{l}\text { Broad } \\
\text { Money } \\
\text { (M3) }\end{array}$ & $\begin{array}{l}\text { Per } \\
\text { Capita } \\
\text { GNP }\end{array}$ & $\begin{array}{l}\text { WPI } \\
\text { S\&P } \\
\text { CNX } \\
\text { Nifty }\end{array}$ \\
\hline Mean & 8.75 & 5.26 & 5.27 & 5.26 & 5.26 & 5.27 & 5.26 & 5.27 & 5.27 \\
\hline Median & 8.00 & 3.90 & 2.40 & 3.90 & 4.60 & 3.90 & 4.90 & 5.30 & 3.50 \\
\hline Minimum & 6.00 & 1.00 & 0.20 & 1.10 & 1.30 & 0.90 & 1.70 & 3.40 & 1.20 \\
\hline Maximum & 12.00 & 14.50 & 18.90 & 15.10 & 12.80 & 15.90 & 11.80 & 7.40 & 16.00 \\
\hline Standard Deviation & 2.52 & 4.27 & 5.77 & 4.33 & 3.29 & 4.24 & 2.87 & 1.18 & 3.85 \\
\hline Kurtosis & -1.69 & -0.21 & 0.37 & 0.01 & -0.33 & 0.22 & -0.36 & -1.12 & 1.39 \\
\hline Skewness & 0.17 & 1.04 & 1.26 & 1.14 & 0.80 & 1.08 & 0.76 & 0.11 & 1.56 \\
\hline Jarque-Bera (JB) & 185.45 & 38.01 & 34.1 & 32.84 & 50.12 & 36.96 & 52.32 & 126.92 & 92.97 \\
\hline Probability & 0.00 & 0.00 & 0.00 & 0.00 & 0.00 & 0.00 & 0.00 & 0.00 & 0.00 \\
\hline
\end{tabular}

Table 2: Correlation Matrix - Key Macroeconomic Variables

\begin{tabular}{|c|c|c|c|c|c|c|c|c|c|}
\hline Particulars & Bank Rate & $\begin{array}{l}\text { Domestic } \\
\text { Savings }\end{array}$ & $\begin{array}{l}\text { Forex } \\
\text { Reserves }\end{array}$ & $\begin{array}{l}\text { GDCF at } \\
\text { Current } \\
\text { Prices }\end{array}$ & $\begin{array}{l}\text { GDP at } \\
\text { Factor } \\
\text { Cost }\end{array}$ & $\begin{array}{l}\text { Broad } \\
\text { Money } \\
\text { (M3) }\end{array}$ & $\begin{array}{l}\text { Per } \\
\text { Capita } \\
\text { GNP }\end{array}$ & WPI & $\begin{array}{l}\text { S \& P CNX } \\
\text { Nifty }\end{array}$ \\
\hline RBI Bank Rate & 1.0000 & & & & & & & & \\
\hline $\begin{array}{l}\text { Domestic } \\
\text { Savings }\end{array}$ & -0.8146 & 1.0000 & & & & & & & \\
\hline Forex Reserves & -0.7775 & 0.9923 & 1.0000 & & & & & & \\
\hline $\begin{array}{l}\text { GDCF at } \\
\text { Current Prices }\end{array}$ & -0.7908 & 0.9985 & 0.9921 & 1.0000 & & & & & \\
\hline $\begin{array}{l}\text { GDP at Factor } \\
\text { Cost }\end{array}$ & -0.8659 & 0.9881 & 0.9752 & 0.9843 & 1.0000 & & & & \\
\hline $\begin{array}{l}\text { Broad Money } \\
\text { (M3) }\end{array}$ & -0.8321 & 0.9903 & 0.9886 & 0.9886 & 0.9942 & 1.0000 & & & \\
\hline $\begin{array}{l}\text { Per Capita } \\
\text { GNP }\end{array}$ & -0.8584 & 0.9840 & 0.9687 & 0.9814 & 0.9971 & 0.9880 & 1.0000 & & \\
\hline WPI & -0.2082 & 0.4242 & 0.4743 & 0.4277 & 0.3615 & 0.4251 & 0.3416 & 1.0000 & \\
\hline $\begin{array}{l}\text { S \& P CNX } \\
\text { Nifty }\end{array}$ & -0.6549 & 0.9518 & 0.9490 & 0.9565 & 0.9123 & 0.9191 & 0.9133 & 0.4171 & 1.0000 \\
\hline
\end{tabular}

The results of correlation matrix revealed that all the selected variables except bank rate and WPI were 
positively correlated with each other. Whereas Bank rate found with a high negative correlation and WPI with a low correlation. As high or low degree of correlation certainly does not signify or rules out causality between the variables under consideration, hence we proceed to apply for further econometric tools such as Augmented Dickey Fuller (ADF) test and Granger causality test.

Table 3: Augmented Dickey Fuller Test for Key Macroeconomic Variables

\begin{tabular}{|l|r|}
\hline Key Macroeconomic Variables & ADF Statistic \\
\hline RBI Bank Rate & -0.2388 \\
\hline Domestic Savings & -0.8708 \\
\hline Forex Reserves & -0.7412 \\
\hline Gross Domestic Capital Formation & -0.8981 \\
\hline Gross Domestic Product & -1.1683 \\
\hline Money Supply (M3) & -1.1217 \\
\hline Per capita Gross National Product & -0.8691 \\
\hline Wholesale Price Index & 0.2123 \\
\hline S \& P CNX Nifty & -0.0872 \\
\hline
\end{tabular}

Note: Stationarity at $5 \%$ level of significance

While analyzing the time series data it is essential to test Stationarity. Stationarity indicates that the statistical properties of a time series do not change over time. The Augmented Dickey Fuller (ADF) test is applied on the selected macro-economic variables to check their stationarity as a precondition of Granger causality and found all the variables were stationary at 5\% significance level i.e., 1.645 (see Table 3). Finally, the results of Granger causality test revealed that there is no bi-directional causality found between macroeconomic variables and mutual fund market (see Table 4). The real economic variables considered during the study period are not significantly influencing the investment of mutual funds.

Table 4: Granger Causality Test for Key Macroeconomic Variables

\begin{tabular}{|c|c|c|}
\hline Direction of Causality (Null Hypothesis) & F-Statistic & Probability \\
\hline Bank Rate does not Granger cause the investments in Indian mutual funds market & 0.0269 & 0.9734 \\
\hline The investments in Indian mutual funds market does not Granger cause Bank Rate & 0.0517 & 0.9496 \\
\hline $\begin{array}{l}\text { Domestic Savings does not Granger cause the investments in Indian mutual funds } \\
\text { market }\end{array}$ & 0.0517 & 0.9496 \\
\hline $\begin{array}{l}\text { The investments in Indian mutual funds market does not Granger cause Domestic } \\
\text { Savings }\end{array}$ & 0.2461 & 0.7820 \\
\hline $\begin{array}{l}\text { Forex Reserves does not Granger cause the investments in Indian mutual funds } \\
\text { market }\end{array}$ & 0.0339 & 0.9667 \\
\hline $\begin{array}{l}\text { The investments in Indian mutual funds market does not Granger cause Forex } \\
\text { Reserves }\end{array}$ & 0.1198 & 0.8871 \\
\hline GDCF does not Granger cause the investments in Indian mutual funds market & 0.0453 & 0.9557 \\
\hline The investments in Indian mutual funds market does not Granger cause GDCF & 0.2066 & 0.8135 \\
\hline GDP does not Granger cause the investments in Indian mutual funds market & 0.0601 & 0.9417 \\
\hline The investments in Indian mutual funds market does not Granger cause GDP & 0.3943 & 0.6746 \\
\hline $\begin{array}{l}\text { Money Supply does not Granger cause the investments in Indian mutual funds } \\
\text { market }\end{array}$ & 0.0486 & 0.9526 \\
\hline $\begin{array}{l}\text { The investments in Indian mutual funds market does not Granger cause Money } \\
\text { Supply }\end{array}$ & 0.2528 & 0.7768 \\
\hline $\begin{array}{l}\text { Per-capita GNP does not Granger cause the investments in Indian mutual funds } \\
\text { market }\end{array}$ & 0.0471 & 0.9540 \\
\hline $\begin{array}{l}\text { The investments in Indian mutual funds market does not Granger cause Per-capita } \\
\text { GNP }\end{array}$ & 0.2416 & 0.7856 \\
\hline WPI does not Granger cause the investments in Indian mutual funds market & 0.0100 & 0.9900 \\
\hline The investments in Indian mutual funds market does not Granger cause WPI & 0.0006 & 0.9994 \\
\hline
\end{tabular}

Note: Stationary at $5 \%$ level of significance 
From the above table 4 , it is evident that the $\mathrm{p}$ values of all macroeconomic variables are greater than $5 \%$ significance level ( $\mathrm{p}>0.05)$ during the study period. Thus the macroeconomic variables considered during the period of study are not significantly influencing the investment in mutual funds.

\section{Conclusion}

This study examined the influence of select macro-economic variables such as, RBI Bank Rate, Domestic Savings, Forex Reserves, Gross Domestic Capital Formation, Gross Domestic Product, Money Supply (M3), Per capita Gross National Product, and Wholesale Price Index on investments in Indian mutual funds market. It is evident from the empirical results that the selected macroeconomic variables are not significantly influencing the investments in mutual funds, even to predict the market movements during study period. Thus, it is interpreted that the selected macro-economic variables neither significant bearing on the mutual fund market nor on the health of mutual fund products. Further, it can be concluded that the select macroeconomic variables do not have any significant influence on investments in Indian Mutual funds market for valid market predictions and worthwhile investment decisions. The study postulate that there are some other macro-economic factors, which might be exerting influence on the investment of mutual funds. Hence, there is a scope for further research in this area by considering some other macro-economic factors to analyze their influence on investments in Indian mutual funds market.

\section{References:}

1. Allen, David E., \& Parwada, Jerry T. (2006). Investor's response to mutual fund company mergers. International Journal of Managerial Finance, 2(2), 121-135.

2. Badrinath, Swaminathan G., \& Gubelline, Stefano (2012). Does conditional mutual fund outperformance exist? Managerial Finance, 38(12), 1160-1183.

3. Bogle, J.C. (1992). Selecting equity mutual funds. The Journal of Portfolio Management, 18(2), 94-110.

4. Deepak Chawla (2014). An Empirical Analysis of Factors Influencing Investment in Mutual Funds in India. Global Business Review, 15, vol 3, 493-503.

5. Emily Chelangat Kariuki (2014), "effect of macro-economic variables on financial performance of mutual funds industry in Kenya", school of business, university of nairobi. November, 2014.

6. G. Dinesh kumar, mihir dash (December 15th 2008)," a study on the effect of macroeconomic variables on indian mutual funds", electronic copy available at: http://ssrn.com/abstract=1316442

7. Ippolito, R. (1992). Consumers reaction to measures of poor quality: evidence from mutual funds. Journal of Law and Economics, 35(1), 45-70.

8. Mohammadreza Monjazeb and Esmaeel Ramazanpour (2013), "The Effect of Economic Factors on the Efficiency of Mutual Funds in Iran Seyedeh Javaneh Ahmadi Tulamy", Technical Journal of Engineering and Applied Sciences TJEAS Journal-2013-3-15/1707-1711 ISSN 2051-0853

9. Ramasamy, B., \& Young, M.C.H. (2003). Evaluating mutual funds in an emerging markets: factors that matter to financial advisors. International Journal of Bank Marketing, 21(3), 122-136.

10. Singh, J., \& Chander, S. (2004). An empirical analysis of perception of investors towards mutual funds. Finance India, XVIII(4), 1673-1692.

11. Tony, Chieh-Tse, H. (2012). Return persistence and investment timing decisions in Taiwanese domestic equity mutual funds, Managerial Finance, 38(9), 873-891.

12. Watson, E., \& Funck, M.C. (2012). A cloudy day in the market: short selling behavioural bias or trading strategy. International Journal of Managerial Finance, 8(3), 238-255.

13. Wilcox, R.T. (2003). Bargain hunting or star gazing? Investors' preferences for stock mutual funds, Journal of Business, 70(4), 645-663.

14. www.amfiindia.com.

15. www.sebi.gov.in 